\title{
PENERAPAN METODE WASPAS DAN MOORA DALAM PENGAMBILAN KEPUTUSAN
}

\author{
Puji Sari Ramadhan ${ }^{1}$, Mukhlis Ramadhan ${ }^{2}$, Muhammad Dahria ${ }^{3}$
}

1,2,3 STMIK TRIGUNA DHARMA

Jl. AH Nasution No.73F, 20142, Indonesia

I pujisariramadhan@gmail.com, ${ }^{2}$ mukhlisramadhan@gmail.com, ${ }^{3}$ mdahria@gmail.com

\begin{abstract}
Abstrak - Penelitian ini membahas tentang perbandingan metode yang digunakan untuk penentuan kelayakan karyawan yang layak untuk mendapatkan beasiswa studi lanjut. Metode yang akan dibandingkan adalah metode Moora dan Waspas. Kedua metode tersebut dipilih karena memiliki kemampuan dalam menghasilkan keputusan. Tujuan dari penelitian ini adalah untuk memilih metode yang paling baik digunakan dalam penentuan keputusan, terutama untuk menentukan kelayakan karyawan untuk mendapatkan beasiswa studi lanjut. Tahapan perbandingan metode dimulai dengan dengan melakukan pengumpulan data kriteria dan bobot penilaian, kemudian menetapkan data alternatif yang akan dinilai. Tahapan selanjutnya adalah melakukan penerapan kedua metode tersebut dan melakukan perbandingan metode melalui perankingan nilai, hasil keputusan dan teknik eksponensial. Berdasarkan penelitian yang telah dilakukan maka diperoleh hasil bahwa untuk nilai keputusan, metode Moora menghasilkan nilai rata-rata 1,1 dan metode Waspas mendapatkan nilai rata-rata 0,5 . Kemudian dari hasil keputusan terlihat kedua metode tersebut menghasilkan keputusan yang sama pada setiap alternatifnya dan untuk teknik eksponensial, metode Moora mendapatkan nilai 1,05 dan metode Waspas mendapatkan nilai 0,73. Berdasarkan hasil tersebut maka dapat diketahui bahwa metode Moora lebih baik dibandingkan dengan metode Waspas dalam pengambilan keputusan.
\end{abstract}

Kata Kunci-Sistem Pendukung Keputusan, Moora, Waspas, Seleksi Beasiswa.

Abstract - This study discusses the comparison of the methods used to determine the eligibility of employees who are eligible for further study scholarships. The methods to be compared are the Moora and Waspas methods. Both methods were chosen because they can make decisions. The purpose of this study is to select the best method used in making decisions, especially to determine the eligibility of employees for further study scholarships. The method comparison stage begins by collecting data on the criteria and weight of the assessment, then determining the alternative data be assessed. The next stage is to apply the two methods and make comparisons of methods through ranking values, decision results, and exponential techniques. Based on the research that has been done, the results show that for the decision value, the Moora method produces an average value of 1.1 and the Waspas method gets an average value of 0.5. Then from the results of the decision, it can be seen that the two methods produce the same decision for each alternative, and for the exponential technique, the Moora method gets a value of 1.05 and the Waspas method gets a value of 0.73 . Based on these results, it can be seen that the Moora method is better than the Waspas method in making decisions.

Keywords — Decision Support System, Moora, Waspas, Scholarship Selection.

\section{PENDAHULUAN}

Penelitian ini akan membahas tentang penerapan metode dalam Sistem Pendukung Keputusan untuk pengambilan keputusan. Kasus yang akan diangkat untuk menguji penerapan metode dalam pengambilan keputusan adalah pemilihan karyawan yang layak mendapatkan beasiswa studi lanjut di STMIK Triguna Dharma. Penggunaan Sistem Pendukung Keputusan dalam kasus tersebut sangat dibutuhkan, mengingat bahwa konsep Sistem Pendukung Keputusan telah teruji dalam menghasilkan keputusan.

Terlihat dalam penelitian sebelumnya, bahwa Sistem Pendukung Keputusan telah digunakan dalam penentuan kualitas pelayanan[1]. Kemudian Sistem
Pendukung Keputusan digunakan untuk pemenang tender[2] dan seleksi karyawan yang akan dimutasi[3]. Dari beberapa penelitian yang telah dikemukakan, maka tentunya Sistem Pendukung Keputusan dapat digunakan untuk menentukan kelayakan karyawan yang mendapatkan beasiswa studi lanjut di STMIK Triguna Dharma.

Sistem Pendukung Keputusan tersebut nantinya berfungsi untuk menghitung nilai yang diperoleh alternatif yang ada berdasarkan kriteria yang ditetapkan. Selain itu dari hasil perhitungan yang dilakukan, maka akan diperoleh pemeringkatan terhadap karyawan yang layak untuk mendapatkan beasiswa studi lanjut. 
Dalam pelaksanaannya, metode Sistem Pendukung Keputusan yang digunakan dalam pengambilan keputusan untuk menentukan kelayakan karyawan yang mendapatkan beasiswa studi lanjut di STMIK Triguna Dharma adalah menggunakan metode Waspas dan Moora.

Kedua metode tersebut dipilih karena mampu menghasilkan keputusan melalui perhitungan dari nilai yang dimiliki alternatif terhadap kriteria yang ada. Kemampuan metode metode Waspas dan Moora dibuktikan dengan penggunaan metode tersebut dalam peneliitian sebelumnya.

Penerapan metode Waspas digunakan dalam penentuan lulusan terbaik[4], selain itu, penerapa metode Waspas digunakan dalam pemilihan lokasi transit [5] dan pemilihan kalayakan supplier[6]. Kemudian untuk penerapan metode Moora telah teruji dalam pengambilan keputusan tentang pemilihan sekolah terfavorit [7], kelayakan pemasok barang bangunan[8] dan seleksi siswa yang layak untuk mengikuti kegiatan magang[9].

Penggunaan metode metode Waspas dan Moora dilakukan untuk membandingkan efektifitas metode tersebut dalam pengambilan keputusan. Hal ini dilakukan untuk mengetahui metode yang paling paling baik dalam pengambilan keputusan untuk pemilihan karyawan yang layak mendapatkan beasiswa studi lanjut di STMIK Triguna Dharma.

Proses penerapan metode Waspas dan Moora dalam pemilihan karyawan yang layak mendapatkan beasiswa studi lanjut, diawali dengan penentuan nilai bobot kriteria yang nantinya akan dihitung dengan nilai alternatif yang diperoleh dari hasil seleksi. Setalah proses perhitungan selesai, maka selanjutnya akan dilakukan perbandingan metode untuk menguji efektifitas metode Waspas dan Moora dalam pengambilan keputusan.

Perbandingan metode akan menggunakan teknik eksponensial. Teknik ini nantinya akan digunakan untuk mengukur hasil keputusan yang diperoleh dari kedua metode tersebut. Teknik eksponensial pernah digunakan dalam penelitian sebelumnya untuk perbandingan metode[10] dan[11].

Dengan adanya penelitian ini diharapkan dapat memberikan referensi haisl keputusan sehingga dapat membantu pihak terkait untuk mempermudah dalam pemilihan kelayakan karyawan yang mendapatkan beasiswa studi lanjut.

\section{LANDASAN TEORI}

Untuk menyelesaikan permasalahan dalam penelitian ini, maka dibutuhkan landasan teoritis yang berkaitan dengan penerapan metode Waspas dan Moora dalam pengambilan keputusan.

\section{Sistem Pendukung Keputusan}

Sistem Pendukung Keputusan merupakan bidang ilmu yang mampu menghasilkan keputusan dari beberapa alternatif [12]. Kemudian Sistem Pendukung
Keputusan dikenal sebagai konsep keilmuan komputasi yang mampu menyelesaikan permasalahan yang berkaitan dengan pemilihan alternatif [13].

\section{Metode Waspas}

Metode Waspas adalah metode yang dihasilkan dari gabungan metode Weight Product dan Simple Additive Weighting [14]. Waspas merupakan metode yang dapat mengoptimalkan pemilihan berdasarkan nilai benefit dan cost. Berikut merupakan fungsi persamaan dari metode Waspas [15] :

1) Mempersiapkan sebuah matriks keputusan: dimana hasil keputusan tersebut diperoleh dari kriteria pada suatu alternatif.

$$
X=\left[\begin{array}{lll}
x_{11} & x_{12} & x_{1 n} \\
x_{21} & x_{22} & x_{2 n} \\
x_{m i} & x_{m 2} & x_{m n}
\end{array}\right]
$$

2) Melakukan normalisasi matriks: Normalisasi bertujuan untuk menyatukan setiap elemen matriks sehingga elemen pada matriks memiliki nilai yang seragam.

$$
\begin{aligned}
& \text { a. Kriteria Benefit } \\
& \mathrm{X}_{\mathrm{ij}}=\frac{x_{\mathrm{ij}}}{\max i x_{i j}} \\
& \text { b. Kriteria Cost } \\
& \mathrm{X}_{\mathrm{ij}}=\frac{\min _{i x i j}}{x i j}
\end{aligned}
$$

3) Menghitung nilai $Q i$ : Alternatif yang terbaik merupakan alternatif yang memiliki nilai Qi tertinggi

$$
Q i=0,5 \sum_{j=1}^{n} X i j w+0,5 \prod_{j=1}^{n}(x i j)^{w j}
$$

\section{Metode Moora}

Metode Moora merupakan metode yang digunakan untuk menyelesaikan perhitungan yang bersifat kompleks[15][16]. Berikut ini merupakan fungsi persamaan dari metode Moora[17] :

1) Mempersiapkan sebuah matriks keputusan: dimana hasil keputusan tersebut diperoleh dari kriteria pada suatu alternatif.

$$
X=\left[\begin{array}{lll}
x_{11} & x_{12} & x_{1 n} \\
x_{21} & x_{22} & x_{2 n} \\
x_{m i} & x_{m 2} & x_{m n}
\end{array}\right]
$$

2) Melakukan normalisasi matriks: Normalisasi bertujuan untuk menyatukan setiap elemen matriks sehingga elemen pada matriks memiliki nilai yang seragam.

$$
X_{i j}=X_{i j} / \sqrt{\left[\sum_{i=1}^{m} X_{i j}^{2}\right]}
$$

3) Mengurangi nilai maximax dan minimax: Alternatif yang terbaik merupakan alternatif yang memiliki nilai Yi tertinggi.

$$
Y_{i}=\sum_{j=1}^{g} W_{j} X_{i j-} \sum_{j=g+1}^{n} W_{j} X_{i j}
$$




\section{Teknik Eksponensial}

Teknik eksponensial digunakan untuk melakukan perbandingan antar variabel atau alternatif[18]. Teknik ini menggunakan perhitungan pemangkatan untuk mencari nilai prioritas dari alternatif yang ada[10].

\section{HASIL DAN PEMBAHASAN}

Pada tahapan ini akan membahas tentang kerangka kerja yang harus dilakukan untuk menyelesaikan permasalahan tentang seleksi kelayakan karyawan yang mendapat beasiswa studi lanjut. Berikut ini merupakan kerangka kerja yang telah ditetapkan:

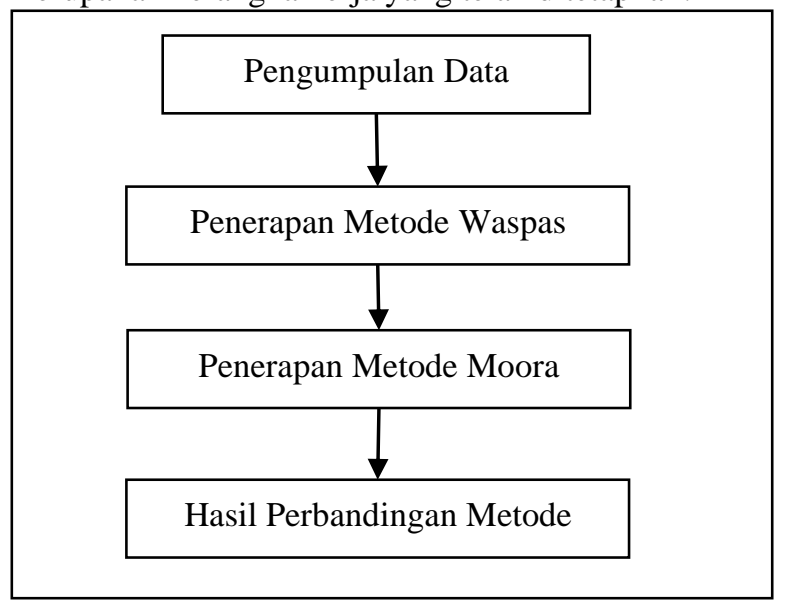

Gbr. 1 Kerangka Kerja Penelitian

Kerangka kerja pada penelitian ini berisi tentang tahapan-tahapan yang akan dilakukan meliputi : pengumpulan data kriteria dan alternatif, penerapan metode Waspas terhadap alternatif yang telah dinilai, kemudian penerapan metode Moora yang akan dilakukan pada alternatif yang ada dan melakukan perbandingan metode Waspas dengan Moora. Sehingga pada akhirnya akan diketahui metode yang paling baik digunakan dalam seleksi kelayakan karyawan yang mendapat beasiswa studi lanjut.

\section{A. Pengumpulan Data}

Tahapan ini akan membahas tentang hasil pengumpulan data yang dibutuhkan dalam penyeleksian karyawan yang layak untuk mendapatkan beasiswa studi lanjut. Teknik pengumpulan data dilakukan dengan cara wawancara oleh pimpinan institusi yang terkait. Data yang berhasil dikumpulkan meliputi : data kriteria penilaian, data alternatif, dan hasil penilaian dari masing-masing alternatif. Berikut ini data-data yang dibutuhkan dalam penelitian ini :

TABEL I

\begin{tabular}{|c|c|c|c|}
\hline No & $\begin{array}{c}\text { Kode } \\
\text { Kriteria }\end{array}$ & Nama Kriteria & $\begin{array}{c}\text { Nilai } \\
\text { Bobot }\end{array}$ \\
\hline 1 & C001 & Kedisiplinan & $40 \%$ \\
\hline 2 & C002 & Wawancara & $20 \%$ \\
\hline 3 & C003 & $\begin{array}{c}\text { Tes Wawasan } \\
\text { Akademik }\end{array}$ & $15 \%$ \\
\hline
\end{tabular}

\begin{tabular}{|c|c|c|c|}
\hline 4 & C004 & Tes Kompetensi & $15 \%$ \\
\hline 5 & C005 & Kinerja & $10 \%$ \\
\hline
\end{tabular}

Setelah menentukan kriteria penilaian, maka tahapan selanjutnya adalah menentukan range bobot dari setiap kriteria. Adapun range bobot dari kriteriakriteria yang telah disusun adalah sebagai berikut :

TABEL III

RANGE KRITERIA KEDISIPLINAN

\begin{tabular}{|c|c|c|}
\hline No & Keterangan & Nilai Bobot \\
\hline 1 & $<5$ & 5 \\
\hline 2 & 6 s.d 8 & 4 \\
\hline 3 & 9 s.d 10 & 3 \\
\hline 4 & 11 s.d 15 & 2 \\
\hline 5 & $>15$ & 1 \\
\hline
\end{tabular}

Range kriteria kedisiplinan diperoleh dari hasil pemantauan absensi selama 1 periode. Kemudian untuk hasil range kriteria wawancara adalah sebagai berikut :

TABEL IIIII RANGE KRITERIA WAWANCARA

\begin{tabular}{|c|c|c|}
\hline No & Keterangan & Nilai Bobot \\
\hline 1 & 80 s.d 100 & 5 \\
\hline 2 & 70 s.d 79 & 4 \\
\hline 3 & 60 s.d 69 & 3 \\
\hline 4 & 50 s.d 59 & 2 \\
\hline 5 & $<50$ & 1 \\
\hline
\end{tabular}

Range kriteria wawancara diperoleh dari hasil tes yang telah dilakukan oleh tim akademik. Kemudian untuk hasil range kriteria tes wawasan akademik adalah sebagai berikut :

TABEL IVV

RANGE KRITERIA TES WAWASAN AKADEMIK

\begin{tabular}{|c|c|c|}
\hline No & Keterangan & Nilai Bobot \\
\hline 1 & 80 s.d 100 & 5 \\
\hline 2 & 70 s.d 79 & 4 \\
\hline 3 & 60 s.d 69 & 3 \\
\hline 4 & 50 s.d 59 & 2 \\
\hline 5 & $<50$ & 1 \\
\hline
\end{tabular}

Range kriteria tes wawasan akademik diperoleh dari hasil tes yang telah dilakukan oleh tim akademik. Kemudian untuk hasil range kriteria tes kompetensi adalah sebagai berikut : 
TABEL V

RANGE KRITERIA TES KOMPETENS

\begin{tabular}{|c|c|c|}
\hline No & Keterangan & Nilai Bobot \\
\hline 1 & 80 s.d 100 & 5 \\
\hline 2 & 70 s.d 79 & 4 \\
\hline 3 & 60 s.d 69 & 3 \\
\hline 4 & 50 s.d 59 & 2 \\
\hline 5 & $<50$ & 1 \\
\hline
\end{tabular}

Range kriteria tes kompetensi diperoleh dari hasil tes yang telah dilakukan oleh tim akademik. Kemudian untuk hasil range kriteria kinerja adalah sebagai berikut :

TABEL VI

RANGE KRITERIA KINERJA

\begin{tabular}{|c|c|c|}
\hline No & Keterangan & Nilai Bobot \\
\hline 1 & 80 s.d 100 & 5 \\
\hline 2 & 70 s.d 79 & 4 \\
\hline 3 & 60 s.d 69 & 3 \\
\hline 4 & 50 s.d 59 & 2 \\
\hline 5 & $<50$ & 1 \\
\hline
\end{tabular}

Range kriteria tes kinerja diperoleh dari hasil pemantauan kinerja selama 1 periode. Berdasarkan data kriteria yang telah ditetapkan, maka proses selanjutnya adalah melakukan pendataan dan penilaian terhadap masing-masing alternatif yang menjadi peserta seleksi. Berikut data peserta seleksi yang telah dinilai :

TABEL VII

HASIL PENILAIAN ALTERNATIF

\begin{tabular}{|c|c|c|c|c|c|c|}
\hline No & $\begin{array}{c}\text { Nama } \\
\text { Alternatif }\end{array}$ & C001 & $\mathrm{CO02}$ & $\mathrm{C003}$ & $\mathrm{CO04}$ & $\mathrm{C} 005$ \\
\hline 1 & $\begin{array}{l}\text { Akbar } \\
\text { Idaman }\end{array}$ & 2 & 2 & 4 & 5 & 5 \\
\hline 2 & $\begin{array}{c}\text { Rini } \\
\text { Susanti }\end{array}$ & 1 & 1 & 3 & 2 & 5 \\
\hline 3 & $\begin{array}{c}\text { Karina } \\
\text { Andriani }\end{array}$ & 4 & 3 & 2 & 1 & 3 \\
\hline 4 & $\begin{array}{c}\text { Kiki } \\
\text { Rilana }\end{array}$ & 2 & 4 & 1 & 2 & 5 \\
\hline 5 & $\begin{array}{c}\text { Ria } \\
\text { Mentari }\end{array}$ & 5 & 1 & 1 & 1 & 5 \\
\hline 6 & Nurlia & 4 & 2 & 4 & 1 & 2 \\
\hline 7 & $\begin{array}{c}\text { Sinyo } \\
\text { Andika }\end{array}$ & 1 & 1 & 3 & 5 & 2 \\
\hline 8 & $\begin{array}{l}\text { Satria } \\
\text { Nanda }\end{array}$ & 5 & 5 & 4 & 5 & 3 \\
\hline 9 & $\begin{array}{c}\text { Edi } \\
\text { Santoso }\end{array}$ & 4 & 5 & 1 & 2 & 5 \\
\hline
\end{tabular}

B. Penerapan Metode Waspas

Setelah proses pengumpulan data dilakukan, maka tahapan selanjutnya adalah melakukan perhitungan dengan menggunakan metode Waspas. Berikut hasil perhitungan dengan menggunakan metode Waspas :
1) Hasil matriks keputusan : diperoleh dari penilaian pimpinan yang telah dikonversi ke nilai bobot sub kriteria. Berikut hasil dari matrik keputusan.

$$
\boldsymbol{x}=\left[\begin{array}{lllll}
2 & 2 & 4 & 5 & 5 \\
1 & 1 & 3 & 2 & 5 \\
4 & 3 & 2 & 1 & 3 \\
2 & 4 & 1 & 2 & 5 \\
5 & 1 & 1 & 1 & 5 \\
4 & 2 & 4 & 1 & 2 \\
1 & 1 & 3 & 5 & 2 \\
5 & 5 & 4 & 5 & 2 \\
4 & 5 & 1 & 2 & 3
\end{array}\right]
$$

2) Hasil normalisasi matriks : diperoleh dari perhitungan yang terdapat pada persamaan 2 dan 3 . Berikut hasil dari normalisasi matriks.

$$
\boldsymbol{x}=\left[\begin{array}{ccccc}
0.4 & 0.4 & 1 & 1 & 1 \\
0.2 & 0.2 & 0.7 & 0.4 & 1 \\
0.8 & 0.6 & 0.5 & 0.2 & 0.6 \\
0.4 & 0.8 & 0.2 & 0.4 & 1 \\
1 & 0.2 & 0.2 & 0.2 & 1 \\
0.8 & 0.4 & 1 & 0.2 & 0.4 \\
0.2 & 0.2 & 0.7 & 1 & 0.4 \\
1 & 1 & 1 & 1 & 0.6 \\
0.8 & 1 & 0.2 & 0.4 & 1
\end{array}\right]
$$

3) Menghitung nilai $Q i$ : diperoleh dari perhitungan yang terdapat pada persamaan 4 . Berikut hasil dari nilai Qi dari masing-masing alternatif.

TABEL VIII

HASIL PERANGKINGAN NILAI Q

\begin{tabular}{|c|c|c|}
\hline No & Nama Alternatif & Qi \\
\hline 1 & Akbar Idaman & 0,61 \\
\hline 2 & Rini Susanti & 0,37 \\
\hline 3 & Karina Andriani & 0,50 \\
\hline 4 & Kiki Rilana & 0,48 \\
\hline 5 & Ria Mentari & 0,54 \\
\hline 6 & Nurlia & 0,46 \\
\hline 7 & Sinyo Andika & 0,33 \\
\hline 8 & Satria Nanda & 0,89 \\
\hline 9 & Edi Santoso & 0,66 \\
\hline
\end{tabular}

\section{Penerapan Metode Moora}

Pada tahapan ini akan dilakukan penerapan dengan menggunakan metode Moora. Berikut hasil perhitungan dengan menggunakan metode Moora.

1) Hasil matriks keputusan : diperoleh dari penilaian pimpinan yang telah dikonversi ke nilai bobot sub kriteria. Berikut hasil dari matrik keputusan.

$$
\boldsymbol{x}=\left[\begin{array}{lllll}
2 & 2 & 4 & 5 & 5 \\
1 & 1 & 3 & 2 & 5 \\
4 & 3 & 2 & 1 & 3 \\
2 & 4 & 1 & 2 & 5 \\
5 & 1 & 1 & 1 & 5 \\
4 & 2 & 4 & 1 & 2 \\
1 & 1 & 3 & 5 & 2 \\
5 & 5 & 4 & 5 & 2 \\
4 & 5 & 1 & 2 & 3
\end{array}\right]
$$


2) Hasil normalisasi matriks : diperoleh dari perhitungan yang terdapat pada persamaan 6. Berikut hasil dari normalisasi matriks

$\boldsymbol{x}=\left[\begin{array}{ccccc}0,3 & 0,4 & 1,8 & 2,6 & 2 \\ 0,1 & 0,1 & 1 & 0,4 & 2 \\ 1,5 & 0,9 & 0,4 & 0,1 & 0,7 \\ 0,3 & 1,7 & 0,1 & 0,4 & 2 \\ 2,4 & 0,1 & 0,1 & 0,1 & 2 \\ 1,5 & 0,4 & 1,8 & 0,1 & 0,3 \\ 0,1 & 0,1 & 1 & 2,6 & 0,3 \\ 2,4 & 2,7 & 1,8 & 2,6 & 0,7 \\ 1,5 & 2,7 & 0,1 & 0,4 & 2\end{array}\right]$

3) Hasil nilai $\mathrm{Yi}$ : diperoleh dari perhitungan yang terdapat pada persamaan 7 .

TABEL IX HASIL PERANGKINGAN NILAI Y

\begin{tabular}{|c|c|c|}
\hline No & Nama Alternatif & Yi \\
\hline 1 & Akbar Idaman & 1,12 \\
\hline 2 & Rini Susanti & 0,48 \\
\hline 3 & Karina Andriani & 0,97 \\
\hline 4 & Kiki Rilana & 0,78 \\
\hline 5 & Ria Mentari & 1,22 \\
\hline 6 & Nurlia & 1,03 \\
\hline 7 & Sinyo Andika & 0,65 \\
\hline 8 & Satria Nanda & 2,25 \\
\hline 9 & Edi Santoso & 1,44 \\
\hline
\end{tabular}

\section{Perbandingan Metode}

Berdasarkan hasil penerapan metode Moora dan Waspas yang telah dilakukan, maka selanjutnya akan dilakukan perbandingan metode. Berikut hasil perbandingan metode yang dilakukan.

1) Mencari Nilai Tertinggi : langkah ini dilakukan untuk mencari nilai tertinggi dari masing-masing alternatif berdasarkan kriteria yang ada. Berikut grafik perbandingan metode Moora dan Waspas.

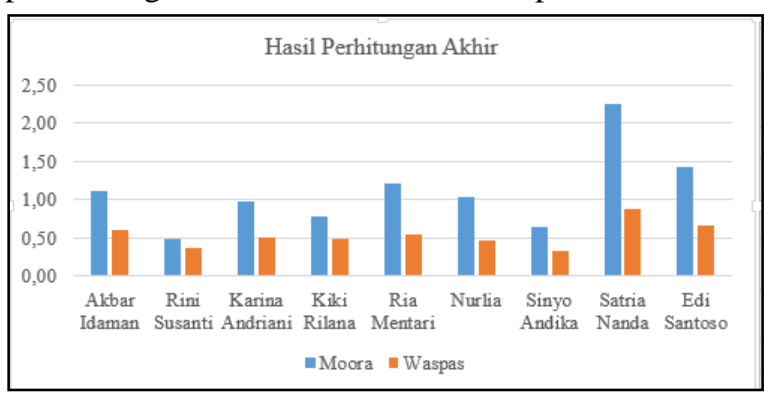

Gbr. 1 Hasil Perhitungan Akhir dari Metode Moora dan Waspas
Dari grafik tersebut dapat terlihat bahwa metode Moora memiliki nilai keputusan lebih tinggi dibandingkan dengan metode Waspas.

2) Hasil Keputusan : berdasarkan penerapan metode yang telah dilakukan dalam kasus penyeleksian karyawan yang layak untuk mendapatkan beasiswa studi lanjut, diketahui bahwa metode Moora dan Waspas memiliki nilai ranking yang sama untuk semua alternatif. Untuk ranking pertama terpilih alternatif atas nama Satria Nanda pada kedua metode tersebut.

3) Teknik Eksponensial : tahapan selanjutnya adalah mengukur efektifitas kedua metode tersebut dengan menggunakan teknik eksponensial. Diawali dengan penentuan nilai bobot eksponensial.

TABEL $X$

BOBOT EKSPONENSIAL

\begin{tabular}{|c|c|}
\hline Alternatif & Nilai Bobot \\
\hline Moora & 0,5 \\
\hline Waspas & 0,5 \\
\hline
\end{tabular}

Setelah menentukan nilai bobot, maka selanjutnya akan dilakukan perhitungan dengan melakukan pemangkatan terhadap nilai rata-rata metode terhadap bobot nilai yang ditetapkan.

TABEL XI

HASIL PERHITUNGAN EKSPONENSIAL

\begin{tabular}{|c|c|c|c|}
\hline Alternatif & $\begin{array}{c}\text { Nilai Rata- } \\
\text { rata Metode }\end{array}$ & $\begin{array}{c}\text { Proses } \\
\text { Eksponensial }\end{array}$ & Hasil \\
\hline Moora & 1,1 & $1,1^{0,5}$ & 1,05 \\
\hline Waspas & 0,5 & $0,5^{0,5}$ & 0,73 \\
\hline
\end{tabular}

Berdasarkan hasil perhitungan dari teknik eksponensial, maka diketahui bahwa metode Moora memiliki nilai lebih tinggi dibandingkan dengan metode Waspas.

\section{KESIMPULAN}

Berdasarkan penelitian yang telah dilakukan tentang perbandingan metode Moora dan Waspas untuk penyeleksian karyawan dalam program beasiswa lanjut studi, maka dapat disimpulkan bahwa dari tiga percobaan yang dilakukan dalam perbandingan metode, dimulai dari nilai tertinggi, hasil keputusan dan teknik eksponensial terlihat metode Moora lebih baik dibandingkan dengan metode Waspas. Dari nilai keputusan metode Moora memiliki nilai rata-rata 1,1 dan metode Waspas memiliki nilai rata-rata 0,5 . Kemudian untuk hasil keputusan, kedua metode tersebut memiliki hasil keputusan yang sama pada setiap alternatifnya. Selain itu, untuk perhitungan teknik eksponensial diketahui bahwa metode Moora memiliki nilai 1,05 dan metode Waspas memiliki nilai 
0,73. Dari hasil tersebut maka dapat diketahui bahwa untuk kasus seleksi karyawan dalam penerimaan beasiswa studi lanjut, metode yang paling baik digunakan adalah metode Moora.

\section{REFERENSI}

[1] P. S. Ramadhan, S. Yakub, and J. Halim, "Analisis Sistem Pendukung Keputusan Menentukan Kualitas Pelayanan Pada Hotel Grandhika Menggunakan Metode Customer Satisfaction Index dan Service Quality," vol. 19, no. 2, pp. 85-93, 2020

[2] R. Y. Ningsih, D. Andreswari, and A. Johar, "Sistem Pendukung Keputusan Penentuan Pemenang Tender Proyek Menggunakan Metode Multi Factor Evaluation Process ( MFEP )," J. Rekursif, vol. 7, no. 2, pp. 144-154, 2019

[3] K. Sukadana, L. Timur, and K. Pos, "Kinerja Multifactor Evaluation Process ( Mfep ) Dalam,” vol. XVII, no. April, pp. 214-217, 2019.

[4] S. M. Harahap, I. Judi, T. Situmeang, and S. Hummairoh, "Implementation of Weighted Aggregated Sum Product Assessment ( WASPAS ) in Determining the Bes Graduates," vol. 5, no. 1, pp. 44-51, 2021, doi 10.30865/ijics.v5i1.2848.

[5] F. R. Naibaho, "Comparison between SAW and WASPAS Methods in Determining the Location of the Transit Warehouse of PT. TG," J. Informatics Telecommun. Eng., vol. 4, no. 2, pp. 393-403, 2021, doi: 10.31289/jite.v4i2.4561.

[6] M. Keshavarz-Ghorabaee, M. Amiri, M. Hashemi-Tabatabaei, E. K. Zavadskas, and A. Kaklauskas, "A new decisionmaking approach based on fermatean fuzzy sets and waspas for green construction supplier evaluation," Mathematics, vol. 8, no. 12, pp. 1-24, 2020, doi: 10.3390/math8122202.

[7] M. Ilham, I. Parlina, A. Maulana, E. K. Lubis, and S. I. Sari, "Sistem Pendukung Keputusan Pemilihan SMA Negeri Terfavorit Kota Pematangsiantar Menggunakan Metode MOORA," vol. 2, pp. 0-4, 2019.

[8] S. Wardani, I. Parlina, and A. Revi, "Analisis Perhitungan Metode Moora Dalam Pemilihan Supplier Bahan Bangunan Di Toko Megah Gracindo Jaya," J. Nas. Inform. dan Teknol. Jar., vol. 3, no. 1, pp. 95-99, 2018.

[9] R. Hafsarah Maharrani and O. Somantri, "Grouping Industrial Class Placement Selection for Students Using MultiObjective Optimization on the basis of Ratio Analysis," $J$ RESTI (Rekayasa Sist. dan Teknol. Informasi), vol. 4, no. 2, pp. 237-242, 2020, doi: 10.29207/resti.v4i2.1532.

[10] P. S. Ramadhan, "Penerapan Komparasi Teorema Bayes dengan Euclidean Probability dalam Pendiagnosaan Dermatic Bacterial," InfoTekJar (Jurnal Nas. Inform. dan Teknol. Jaringan), vol. 4, no. 1, pp. 1-7, 2019, doi: 10.30743/infotekjar.v4i1.1579.

[11] P. S. Ramadhan, "Perbandingan Multiple Regression dengan Fuzzy Tsukamoto Dalam Memprediksi Produksi Barang," Inform. Mulawarman J. Ilm. Ilmu Komput., vol. 2, pp. 0-6, 2020.

[12] I. Rizky and F. Riandari, "Decision Support System for HP Android Selection using FMADM Model ( Fuzzy Multiple Attribute Decision Making ) with Weight Product ( WP ) Method," J. Teknol. Komput., vol. 14, no. 2, pp. 374-383, 2020.

[13] P. S. Ramadhan, "Penerapan Multi Factor Evaluation Process Dalam Penerimaan Asisten Dosen Pada STMIK Triguna Dharma," J. Media Inform. Budidarma, vol. 3, no. 3, p. 183, 2019, doi: $10.30865 / \mathrm{mib} . v 3 i 3.1184$.

[14] P. S. Ramadhan, "Sistem Pendukung Keputusan dalam Menenetukan Calon ( Tailor ) Penjahit di Ranhouse Medan dengan Menggunakan Metode AggregatedSum Product Assesment," vol. 3, no. 2, pp. 12-24, 2020.

[15] S. Barus, V. M. Sitorus, D. Napitupulu, M. Mesran, and S Supiyandi, "Sistem Pendukung Keputusan Pengangkatan Guru Tetap Menerapkan Metode Weight Aggregated Sum Product Assesment (WASPAS)," J. Media Inform. Budidarma, vol. 2, no. 2, pp. 10-15, 2018, doi: 10.30865/mib.v2i2.594.

[16] A. Ristadi, "Penentuan Lokasi Industri Menggunakan Metode WASPAS Dengan Data Spasial Sebagai Data Kriteria," vol. 1, no. 1, pp. 19-25, 2017.

[17] Sunardi, "Pengambilan Keputusan Sistem Penjaminan Mutu Perguruan Tinggi," vol. 1, no. 10, pp. 350-358, 2021.

[18] P. S. Ramadhan, Marsono, J. Hutagalung, and Y. Syahra, "Comparison of Knowledge-Based Reasoning Methods to Measure the Effectiveness of Diagnostic Results," J. Phys. Conf. Ser., vol. 1783, no. 1, 2021, doi: 10.1088/1742$6596 / 1783 / 1 / 012049$. 